DOI 10.37882/2223-2982.2021.01.34

\title{
ВЛИЯНИЕ ЭМОЦИОНАЛЬНО-ВОЛЕВОЙ СФЕРЫ НА ДВИГАТЕЛЬНУЮ АКТИВНОСТЬ ВЕЛОСИПЕДИСТОВ В ПРЕДСОРЕВНОВАТЕЛЬНЫЙ ПЕРИОД
}

\section{THE INFLUENCE \\ OF THE EMOTIONAL-WILL SPHERE ON THE MOTOR ACTIVITY OF BIKES IN THE PRE-COMPETITIVE PERIOD}

\section{N. Tulupchi \\ K. Poskonina}

Summary: The aim of the study was to identify the significance of the influence of the emotional-volitional sphere on the performance of an athlete. The article reveals that the emotional-volitional sphere has a significant impact on the performance of cyclists, and the closer the competitive period, the more the emotional background increases and the athlete's activity becomes intense. The effectiveness of the application of the developed program of complex application of methods of mental self-regulation in the period of preparation for the competition and its influence on the performance of sportsmen-cyclists were revealed.

Keywords: psychological training, physical activity, sportsmen-cyclists, training process, pre-competition training.
Тулупчи Наталья Викторовна

к.п.н., дочент, ФГАОУ ВО «Южный федеральный университет», Ростов-на-Дону nvtulupchi@sfedu.ru

Посконина Кристина Александровна

ГБПОУ Ростовской области «Ростовское областное училище (колледж) олимпийского резерва»,

Ростов-на-Дону

krisposhka@mail.ru

Аннотация: Целью исследования стало выявление значимости влияния эмоционально-волевой сферы на результативность спортсмена. В статье раскрыто, что эмоционально-волевая сфера имеет значительное влияние на результативность велосипедистов, и чем ближе соревновательный период, тем больше увеличивается эмоциональный фон и деятельность спортсмена становится напряжённой. Выявлена эффективность применения разработанной программы комплексного применения методик психической саморегуляции в период подготовки к соревнованиям и ее влияние на результативность спортсменов-велосипедистов.

Ключевые слова: психологическая подготовки, двигательная активность, спортсмены-велосипедисты, тренировочный процесс, предсоревновательная подготовка.

МСМК по велосипедному спорту на треке Дианой Климовой - Чемпионкой Европы, многократного призера Кубков Мира, выявлен тот факт, что в велосипедном спорте уделяют недостаточное внимание психологической подготовленности. Слова одной из ведущих спортсменок: «Спортсмены Чемпионы России приезжают за границу на Чемпионат Европы, Мира и тут же теряются, сразу пропадает уверенность в себе, кто-то пытается себя эмоционально сдерживать, но сами понимаете, каких затрат это стоит. И к чему это приводит? Не выполнили свой результат, не потому что слабые, а потому что психологически не готовы. Перегорели, испугались»позволили считать, что поиск различных форм психологической подготовки спортсменов-велосипедистов является актуальной темой исследования.

С целью сбора информации о психологической подготовке спортсменов, был проведен опрос в форме анкетирования 10 человек разной квалификации, занимающихся велосипедным спортом, из которых 8 спортсменов - кандидаты в мастера спорта (КМС), 2 спортсмена - мастера спорта (МС). Респондентами являлись спортсмены-велосипедисты Профессионального велосипедного клуба «Boqpod.ch» и учащиеся ГБПОУ РО РОУОР. Сбор информации осуществлялся анонимно путем 
распространения среди респондентов разработанной анкеты, включающей вопросы по проблеме «Влияние эмоционально-волевой сферы на двигательную активность спортсменов-велосипедистов в предсоревновательный период».

Проведенное анкетирование среди спортсменов, привело к следующему выводу, что у $60 \%$ опрошенных спортсменов психологическая подготовка отсутствует, либо осуществляется самостоятельно, исходя из своего профессионального опыта, вследствие чего их предстартовое состояние имеет пагубное влияние на высокую результативность в их соревновательных выступлениях. Они испытывают такие эмоции, как страх, тревогу, неуверенность, такие состояния, как «мондраж» и перегорел. У $20 \%$ опрошенных спортсменов психологическая подготовка присутствует периодически, вследствие чего их эмоциональное состояние в предсоревновательный период меняется, спортсмен может чувствовать себя уверенно и спокойно, а может испытывать неуверенность и тревогу. У оставшихся 20\% спортсменов, психологическая подготовка присутствовала на уровне с физической. Спортсмены уделяли этой сфере должное внимание и их эмоциональное состояние в предстартовый период положительно сказывалось на выступлениях в соревнованиях.

При ответах на вопрос: «Испытывали ли вы необходимость помощи психолога, тренера или самостоятельные знания в управление своими эмоциями в предсоревновательный период?»: 50\% опрошенных спортсменов ответили, что нуждаются в помощи тренера или психолога, чтобы научится контролировать свое эмоциональное состояние в предстартовый период; 30\% ответили, что помощь им была необходима лишь в некоторых случаях; $20 \%$ ответили, что не нуждаются в помощи.

Многие тренеры считают, что всю подготовку спортсменов нужно уделять только физической, тактической и технической подготовке, забывая про психологическое состояние спортсменов, которое они могут испытывать, как во время всей подготовки к соревнованиям, так и в предсоревновательный период.

Вопрос «Считают ли спортсмены нужным уделять внимание психологической подготовке?». Из опрошенных спортсменов все $100 \%$ ответили - «Да, нужно».

Таким образом, анкетирование позволило определить, что уровень психологической подготовки у многих опрошенных спортсменов очень низкий, спортсмены испытывают трудности в управлении своими эмоциями в предсоревновательный период. Ведь именно он отличается наибольшим эмоциональным фоном. Спортсмены управляют своими эмоциями с помощью накопленного профессионального опыта. Анкетный опрос свидетельствует о том, что у большинства спортсменов на практике отсутствует психологическая подготовка, от которой зависит их предстартовое состояние.

Психологическая подготовка включает в себя работу с психологами, тренерами, использование методик психической саморегуляции. При изучении проблемы «Влияние эмоционально-волевой сферы на двигательную активность велосипедистов в предсоревновательный период» пришли к выводам, что у $60 \%$ опрошенных спортсменов не было психологической подготовки, спортсмены испытывали трудности с контролем эмоций в предсоревновательный период, у 20\% психологическая подготовка присутствовала частично, у 20\% присутствовала полностью. Также 50\% процентов опрошенных спортсменов ответили, что нуждались помощи тренера или спортивного психолога в данный период, а еще $30 \%$ ответили, что периодически нуждались в помощи специалиста.

Разработана и внедрена в тренировочно-соревновательный процесс 4-х недельная «Программа комплексного применения методик психической саморегуляции в период подготовки к соревнованиям», с различными объемами тренировочных нагрузок и обязательным включением в процесс занятий психологической направленности, которая показала свою эффективность. После применения программы в процессе предсоревновательной подготовки спортсменов в 2020 году результаты по сравнению с предыдущим годом улучшились от 0,02 до 0,04 секунд в индивидуальной гонке преследование на треке на 2 км и 3 км (рис. 1)

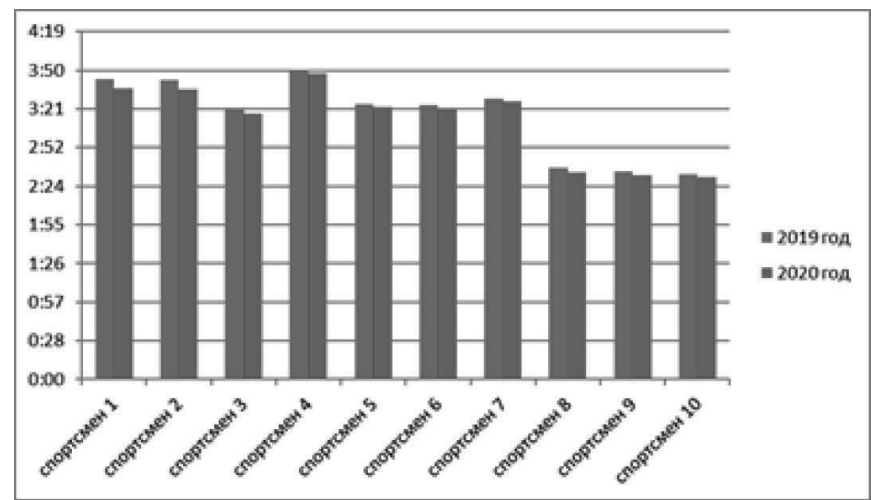

Рис. 1. Сравнительные результаты участников педагогического эксперимента соревновательного сезона 2019 г. и 2020 г.

Психологическая подготовка к конкретному соревнованию заключительный этап всей психической подготовки, применяемой в процессе учебно-тренировочной и соревновательной подготовки. Важнейшая задача этого этапа - формирование оптимального психологического предстартового состояния, при котором спортсмен способен не только проявить свои 
лучшие спортивные качества, но и превзойти их. Еще задолго до начала соревнований у спортсмена рефлекторно возникает напряженность, волнение, повышается частота сердечных сокращений, происходит изменение мышечного тонуса, что вызывает ответные психические и двигательные реакции организма и появляется «мондраж». Полученные результаты использования разработанной программы доказывает значимость влияния адекватного эмоционального состояния в предсоревновательный период на двигательную активность спортсмена и всей психологической подготовки в целом.

\section{ЛИТЕРАТУРА}

1. Вяткин Б.А. Управление психическим стрессом в спортивных соревнованиях. М.: ФиС. 2001.-193с.

2. Ильин Е.П. Психофизиология физического воспитания. Факторы, влияющие на эффективность спортивной деятельности. М.: Просвещение, 2003. -820с.

3. Родионов А.В. Влияние психологических факторов на спортивный результат. М.: ФиС, 2003. -120с.

4. Шайхтдинов Р.3. Личность и волевая готовность в спорте. - М.: Физкультура и спорт, 2007. -143с.

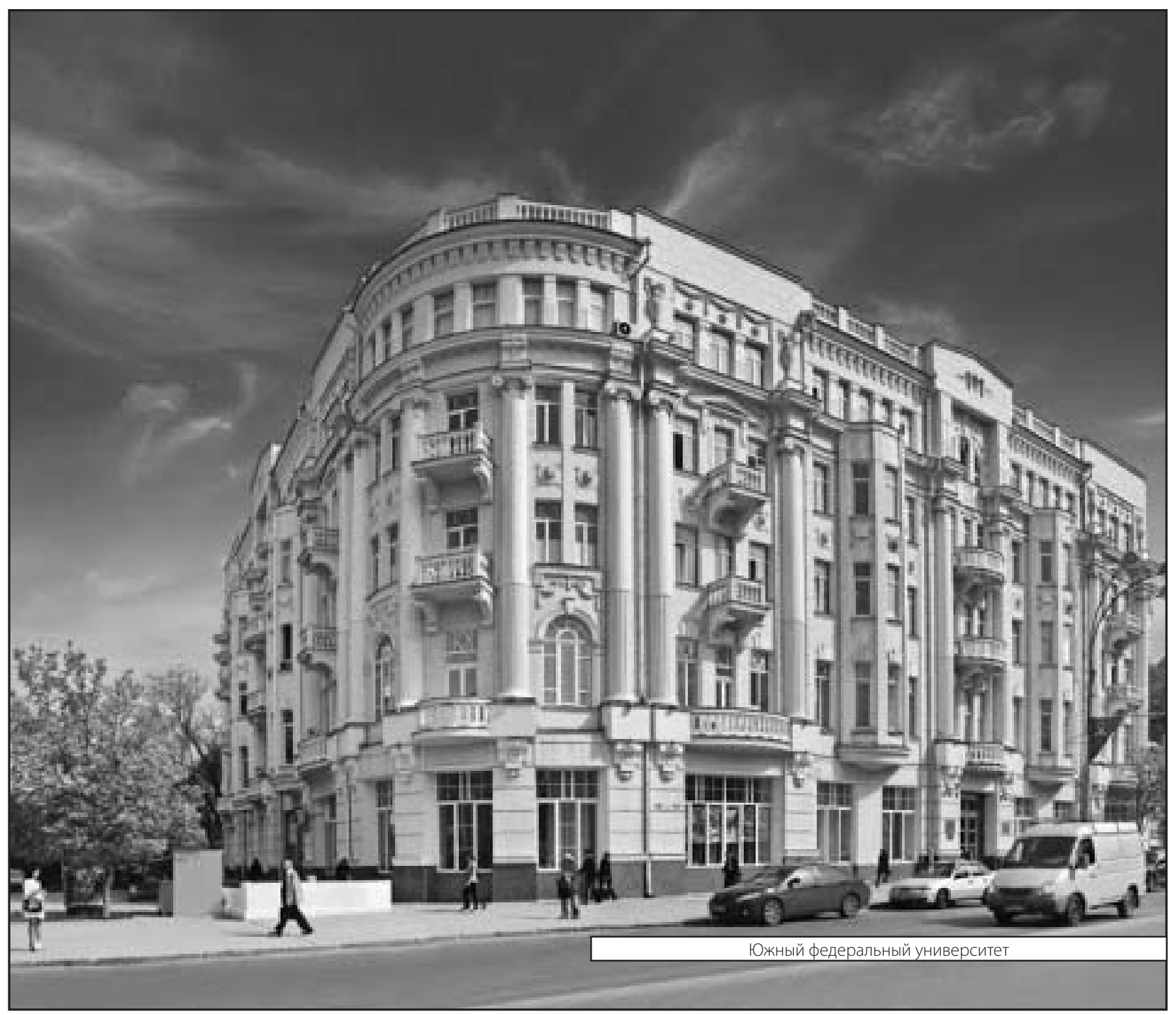

